\title{
A Linguistic-Stylistic Representation of Women Oppression in Selected Calixthe Beyala's Novels
}

\author{
Jummai Lucy JIBRIN \\ National Open University of Nigeria, Abuja, Nigeria
}

\begin{abstract}
Calixthe Beyala is a notable French writer whose works have attracted readership across the globe. Previous studies have examined Calixthe Beyala's novels from feminist, psychological, and systemic function linguistic points of view with insufficient attention paid to the linguistic stylistic features in Calixthe Beyala's novels. This study, therefore, examines linguistic-stylistic representation of women oppression in Calixth Beyala's novels. Four novels of Calixthe Beyala are purposively selected and form the data for this study. The study reveals that linguistic-stylistic features-culture words, contraction of words, neologism, pidgin French, direct transfer of African expressions characterize Beyalian novels. These linguistic-stylistic features depict women oppressions in a male-dominated African society, negritude experience outside the shores of Africa and are a representation of the socio-cultural, political, and economic realities and experiences in Cameroon in particular and Africa in general.
\end{abstract}

Keywords: women oppression, Calixthe Beyala, linguistic-stylistics, and women representation

DOI: $10.7176 / \mathrm{JLLL} / 75-07$

Publication date: January $31^{\text {st }} 2021$

\section{Introduction}

Linguistic stylistics is quite different from literary stylistics. A linguistic stylistician examines elements of a language using scientific analytical approach. Literary stylistics, on the other hand, depends on external factors such as history, philosophy, inspiration, personal experience in the analysis of a text. It can be said that linguistic stylistics is in-text while literary is out-text. Linguistic stylistics pays attention to linguistic features in a text. Such text could be conversation, legal documents, newspapers, and others. Isidore (2010) avers that:

\begin{abstract}
Linguistic stylistics is concerned with the quest for matter and manner in a work of art. It concerns itself with a scientific study of applying linguistic techniques to a work of art with the aim of presenting the merits and demerits. It rigorously analyses and synthesises the work, examining how a special configuration of language has been used in the realisation of a particular subject matter, quantifying all the linguistics means that coalesced to achieve a special aesthetic purpose.
\end{abstract}

What can be inferred from the above is that linguistic stylistics invents and describes stylistic stimuli with the aid of linguistic concepts and variations. Such variations could be according to time, era, socio-dialect, idiolect, register, regiolect and so on. According to Crystal and Davy (2003), a linguistic stylistician is a trained person in the art of analysing the pros and cons of a text. Crystal and Davy assert that:

The stylisticians, ideally, knows three things which linguistically untrained people do not; he is aware of the kind of structure language has, and thus the kind of feature which might be expected to be of stylistics significance; he is aware of the kind of social variation which linguistics features tend to be identified with; and he has a technique of putting these features down on the paper in a systematic way in order to display their internal patterning to maximal effects.

What can be suggested is that a linguistic stylistician examines the internal linguistic patterning in a text. This is with a view to explicating meanings inherent in a text. Linguistic stylistics examines the internal elements and features in a text with a view of making general statements about how these elements cohere to achieve unity or simply put textuality in a text.

This study investigates linguistic-stylistic representation of women oppression and subjugation in Calixthe Beyala's novels. Calixthe Beyala is a francophone writer, whose works have attracted readership nationally and globally. Born in 1961 in the city of Eton, Beyala was brought up and influenced by her 
grandmother. At the age of seventeen, Beyala migrated to France where she wrote baccalaureate and later became a writer. Beyala was known for her tactical expressions of her world of fantasies in her literary expression. Having published her first novel titled The Sun Has Looked Upon Me in 1987, Calixthe founded an organisation that promotes social and political equality for people particularly migrants and the blacks in France two years later. Calixthe Beyala published her second novel titled Loukoum: The Little Prince of Belleville in 1995.

Among the thematic preoccupations in Calixthe Beyala's novels are poverty, violence, corruption, illiteracy, sexuality, female body, child-trafficking, subjugation of women and girl-child, sexual abuse, oppression and subjugation and indispensable roles of women. Nfah-Abbenyi (1997) opines that:

Beyala subverts and politicises not only "woman" but the woman's body experiences. She achieves this by articulating a sexual politics that need not necessarily define womanhood in relation to motherhood. Identity, subjectivity, and sexuality are intricately linked.

This suggests that Beyala focused on the concept of identity, subjectivity, sexuality, womanhood, and female body. This study therefore examines the linguistic stylistic representation of women oppression and subjugation in selected works of Calixthe Beyala with a view to unmasking how Calixthe Beyala reflects and categories women oppression and subjugation in a male-dominated African society.

\section{Statement of the problem}

Previous studies have investigated Calixthe Beyala's works from psychological, feminist, stylistic, thematic, and sociolinguistic points of view (Olayinka, 2014; Halimi 2015; Adetuyi, 2017; Olayinka, 2018; and so on). Mutunda (2009) examines aspects of masculinity in the francophone African women's writing of the twenty-first century. Selecting six francophone women writers and situating the work within Robert Connell's (2005) perspective on masculinity, the study uncovers three types of masculinities which are evident in a male-African dominated society namely: hegemonic, alternative, and ambiguous masculinity. While Matunda's work examines how francophone women writers depict masculinity through characters and characterisation, our focuses on the depiction of women oppression in the works of Calixthe Beyala. Olayinka (2014) investigated how juvenile disorders are portrayed in selected works of Calixthe Beyala. The study, with bias from Freudian psychoanalytic and Nietsche's resentment theories, showed Calix the Beyala's angst against oppression, girl-child abuse, violence and women oppression in a male-dominated African society. The study condemns in its entirety gender discrimination, female-sexuality control, girl-child commodification, marriage, forced marriage, motherhood, widowhood, and rape, incest or paedophilia and others which have become the order of the day in Africa.. While Olayinka examines Calixthe Beyala's works from psychological approach, ours is purely a linguistic-stylistic analysis of selected Beyalian texts. Also, Halimi (2015), with orientations from existentialist points of view, studies the question of "self" and women identities in Beyalian novels. The study investigates the construction of women identities within the ambits of social and fictional francophone contexts. While Halimi investigates the construction of women identities in Calixthe Beyala's works, ours focusses on the linguistic-stylistic representation of women oppression in Calixthe Beyala's works.

Furthermore, Adetuyi (2017) mainly investigates the thematic preoccupations of Nigerian literature. Among prominent thematic concerns in the Nigerian novels are reincarnation, anti-colonialism, gender, religions, feminism, marriage, love, morality, mortality and politics. The similarity of this study with the current work is that they both examined the works of Calixth Beyala. However, there exist a lot of dissimilarities. While Ajibade focusses on the themes, ours is done through the lens of linguistic-stylistic analysis. Finally, Olayinka (2018) specifically examines how female bodies are portrayed in Beyalian novels with a view to unmasking socio-cultural representation of the bodies. With female bodies as object of man's oppression, ridicule and denigration, the study asserts that the bodies have become oppressive tools of taboos, marriage, maternity, servitude, excision, infibulations, and virginity test and so on. Thus, women need to resist, exterminate, and overturn these oppressive tools in order to create a new female image and identity. While this work examines the representation of female bodies in exterminating women oppressions in Beyalian novels, the current study examines how women oppression are depicted in Beyalian novels through the lens of linguistic-stylistic analysis.

From the foregoing, it can be observed previous studies have paid little or no scholarly attention to the linguistic-stylistic analysis of women oppression in Beyalian novels. This study, therefore, examines how women oppressions are depicted in Beyalian novels with a view to revealing the personal and social experiences of Calixthe Beyala through the lens of linguistic-stylistic analysis. 


\title{
Analysis and Discussion of Findings
}

This study focuses on the lexico-stylistic choices in the representation of women oppression and subjugation in Calixthe Beyala's novels. The lexical choices under consideration are cultural words, transposition of words, direct transfer of African expression, the use of pidgin French, contraction of words, neologism as a stylistic feature, substantive nouns and adjectives, and lexical verbs and adjectives. Let us examine each of these lexical choices in their representation of women oppression in selected Calixthe Beyala's novels.

\section{Cultural word}

The cultural word is a reflection of specific socio-political and cultural problems of Africa. Each text focuses on specific socio-political and cultural problems of Africa. CSB deconstructs the illusions that African women are products of negritude movements. Such cultural words include "maisons delapedées" (dilapidated buildings), "la misere" (misery), "viole" (disvergin) "amères" (biter) "couture" (culture), "dispotes absolu" (absolute despot), "silence des femmes" (silence of women) and so on. The words are the true portrayal of the women oppression in the texts. In another instance, the narrator introduces Ateba in her thought as she soliloquises:

\section{Excerpt 1:}

English translation

\begin{abstract}
'Mais Mois, don't les tenèbres avaient rendu la presence aussi invisible que l'invisible, je savais que la bouche mentait, je savais que se tendaient timmidement pour leur dose de prescriptions mentaient, tous mentaient... car tous ignoraient que derriere la jeune fille de dix neuf ans qui errrait

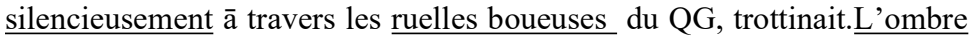
de la femme qui, chaque jour, a l'heure du soir, regardait fièrement le resseau qui traversait le quartier et se demendait quelle allait being pouvoir faire. J'étais la seule a comprendre son désarois. J'écoutais, je compatissait je me proposait de l'aider de mon mieux. J'appelais les astres, je chombolais les états d'âme, personne ne m'écoutais les études d'ãme, personne ne m'écoutait, personne ne me regardais, tous s'occupaient plus de leurs morceau vide role que de moi, en un mot JE GENAIS, j'encombrais, il etait tenu que je regagne ma place auprès des astres. Je

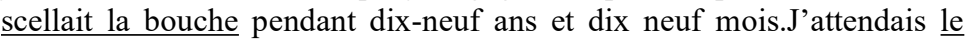
niment opportune, cor le sage come l'espirit ne doit repondre qu'āa

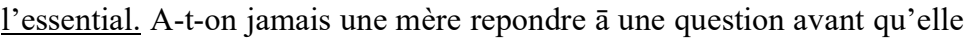
ne soit posée?
\end{abstract}

But I, whose darkness had made the presence as invisible as the invisible, I knew that the mouth was lying, I knew that they were tensing up for their dose of prescription lied, all lied ... because they did not know that behind the young Nineteen-year-old girl who roamed silently through the muddy alleys of the headquarters, scampered. The shadow of the woman who, every day, at evening time, was fleeing the net that crossed the neighborhood and wondered what was going to be. i was the only one to understand his distress. i listened, i sympathized, i offered to help him as best as i could. I called the stars, ibecame restless in my state of mind, no one listened to me studies of love, nobody listened to me, nobody looked at me, all took care more of their piecevide role than me, in a word, $i$ was restless, i was sinking, it was known that i return to my place near the stars. I sealed my mouth for nineteen years and nineteen months. I waited for the opportune niment, the wise man as the spirit must answer only the essential. Is there ever a mother answering a question before she is asked?

Here, the meanings of the underlined words are "ténébres" (darkness), "invisible" (invisible), "l'invisible" (the invisible), "la bouche mentait"(the mouth lies), "tous ignoraient" (all were ignorant of) "erraient silencesieusement" (all wondered silently) "ruelles boueuses" (narrow mody streets), "l'ombre de la femme" (a woman's shadow), "desarois" (despair) "chambolais", (to be restless), "Je genais", (I'm disturbed), "sellait la bouche (to seal one's mouth), moment opportune" (the right time), "repondre qu'ā l'essentiel" and so on. All these words show that women are oppressed. For instance, "to be restless" and reveals that women are objects of ridicule. 
The women and girl-child were restless after being sexually molested by men. The women are ridicule and stigmatised because of the socially and culturally imposed prejudice.

\section{Word Cluster}

Word cluster consists of lexical items which are repeated in sequence. The lexical items include adjectives, verbs, substantives and nominal. Each of lexical items is expatiated below:

\section{Lexical verbs}

Lexical verbs are action words or words that express a state of being. The following examples from MAA and TTT are the instances of lexical verbs in Beyalian novels. The verbs are used to connote the oppression of women who want to be free from the shackles of not only men bu white women. Instances of women oppression through lexical verbs are exemplified below:

\section{Excerpt 2:}

English translation

Puis vint Abdou et l'éxil.Je voulait partir.Abondonner cet horizon de bouet de suie ou le crime se justifie par le bonheur de suspendre. Je voulais partir, acheter ma liberté un rêve de naive éternité'MAA:9.

Then came Abdou and the exile. I wanted to depart. To abandone this horizon of soot bag or crime been justified by the happiness of suspending. I wanted to leave, buy my freedom a naive dream forever "MAA: 9.

The author is concerned with how the black woman had sought to get her freedom from the maledominated African society. It can be noted that the position of a woman is at the feet of her husband. She is sexually subjected and oppressed, socially victimised, materially stigmatised and subjugated. She is to procreate and to carry out all the house chores. It must be noted that her place is confined to the house. Let us consider the following excerpts:

\section{Excerpt 3:}

'Faut pas desesperer.Mêmem,les idiots trouvent des gonzesses. D'ailleurs mon papa dit qu'l y a beaucoup plus de femmes que d'hommes sur la terre'. MAA: 81

English translation

'Do not despair. Even idiots get women. Moreover my father said there are more women than men on earth.'

The excerpt 3 above revealed that women are not a scarce commodity. Women are readily available to the extent that even the idiots can get one. This corroborates Buchi Emecheta's Second Class Citizens. Women are regarded as second class citizens. They are to be used and dumped at will. Another method of oppression is that because women are more than men, then women are to be ridiculed and oppressed. This means that she thinks women are less important than men. Let us consider the excerpt below:

\section{Excerpt 4 :}

“'Desormais, je m'armerai contre le malheur j'arrengerai mon histoire, je lui donnerai le soufflé des fables amoureuses, j'assasinerai mes monsters

English translation et les offrirais en sacrifice aux puissance célestes.'(TTT: 33)

Henceforth, I will arm myself against misfortunes, I will organise my story, I will give it the breath of love, I will assassinate my monsters and offer them as sacrifice to the powerful celestials."

In TTT, Beyala uses a cluster of verbs to x-ray Tanga's prostitution. The act of prostitution is not intentional but occasion by the socio-economic degradation and depression. The income she made from promiscuity is used to feed her family including men. The psychological effects of the promiscuity are disastrous to the moral values. The implication of the above is that Tanga murdered sanctity and desecrate her body in order to cater for her family.

\section{Substantive nouns and adjectives}

Substantive nouns are used to express existence. Bayela uses a number of substantive nouns in a single sentence in order to thematise socio-cultural, issues. Nouns and adjectives elucidate the message of Beyala. For instance, 
In TTT, Beyala uses Anna-Claude to portray the socio-cultural oppression and depression suffered by Tanga and her room-mates in the prison. This is exemplified below :

\section{Excerpt 5:}

English translation

Dans la cellule maintenant couverte d'ombre, Anna-Claude tournoie, ouverte ā l'angoisse Tantôt aigle, vipère, oie, crabe, elle avance dans les mots (TTT. p 13).

In the cell, now dark with shadow, Anna-Claude twists and turns, exposed to her anguish. Now an eagle then a viper, a goose, a crab. She moves forward in words.

In the excerpt above, Beyala exposses the depression suffered by Anna-Claude in the new independent African state. Africa has suffered greatly under colonial masters. After independence, many people thought there is hope for a new African nation. Beyala illustrated the state of disaffections and disillusionments that are characteristic of independent African nation. In the new nation, the indigenes are being maltreated by the so-called compatriots and nationalists. Those who protest against the government ills, vices such as maladministration, corruption, and assassination, and others were arrested, victimized and sentence by the government. The police arrest the people without any proper evidence, beat and lock them up in the prison without any explanation. Beyala uses indigenes, who live in ghetto to depict the pitiable conditions of Africans. In CSB, Beyala asserts that Africans live below one dollar per day and this exemplified below :

\section{Excerpt 6:}

English translation

Chaleur humide ciel blanc hypnotique. Les facades des maisons ressemblent ă des vieilles dames ridées et les vieilles dames ressemblent ã de vieux bidons rouillés, les uns comme les autres rongés par la vie, monifiés par l'attente de la vie (CSB, pp 9)

A humid weather. A hypnotic white sky.The fronts of the houses resemble wrinkled old ladies and the old ladies look like old, rusty plastic cans all of them gnawed at by life, mummified endlessly waiting for life.

In the excerpt above, Beyala revealed French administrative system in its colonies. What can be depicted is that the indigenous traditional systems were left without much improvement. Through French policy of assimilation and association, the political systems and community leaderships were rendered impotent. This is opposed to the British's indirect rule, where kings, emirs and Igwes were part of the leaderships. In the indirect rule, there is room for self-rule without much influence from the Africans. The only thing is the elites were excluded from the policy decision making body. There is no much value added to them by the French colonial masters. From the description of the 'Quartier Général' settlement, it is apparent that there is no development in the French colonies and the people are disillusioned and oppressed. Let us consider the excerpt below:

\section{Excerpt 7 :}

M'am'était coiffée avec des pompoms qui pendant comme sur un sapin de Noel.Elle portrait un pantalon argenté si collant qu'il revelait tous ses muscles.Une ceinture plus large que la pomme de ma main ornait sa taille English translation ses seins pointaient comme deux cornes de buffle (MAA Pg .182)

M'am was wearing pompoms on her hair that look like a Christmas tree. She portrays a silver trouser so sticky that revealed all her muscles. A belt wider than the apple of my hand adorned her waist, her breasts pointed like two buffalo horns (MAA:182)

The above excerpt suggests that Beyala vividly described the physical appearance of Ateba. Her breast posture was described as pointed buffalo horns. The description was to reveal sexual fragility of the African women. Beyala's style illustrates the loss of identity and the inferiority of Africans migrants in MAA, while describing the past life of Maryam as a good housewife. This can be observed in excerpt 8 below: 


\title{
Excerpt 8:
}

Avant, M'am était une bonne ménagère, une bonne cuisinière, et une bonne mère pour nous, papa n'aurait pas pu trouver mieux même en cherchant bien.Qui a rampu l'équillibre? Que s'est-il passé pour que M'am abandonnes ses attributions conjugales? Pourquoi ne joue t'elle plus de la bénédiction nuptiale?', (MAA p184)

English translation

'M'am used to be a good home maker, a good cook, and a good mother to us, and father could not get a better wife even by searching thoroughly. Who has destabilised the equilibrium? What has caused M'am to abandon her conjugale qualities? Why is she not enjoying her marital blessing: the state of helplessness and atrocities M'am found herself in, due to lack of satisfaction with her marital life, couple with the emotional suffering she underwent in Abdou's hand.

What can be observed is that Maryam was a fulfilled house wife. Because of her greediness and avarice, Maryam began to mess around with the monsieur Tichit. The stylistic effect is aimed to emphasis the various images and messages conveyed. There is also strong effect of satire in the way these words are put together in clusters. Beyala uses a number of substantive nouns in a single sentence. This is aimed to effectively convey her message effectively. In MAA, a disillusioned turbulence marital situation, M'am laments by talking to herself.

\section{Excerpt 9:}

English translation

\begin{abstract}
'Mais Abdou ne m'aimait plus.Je le suvais, je le sentais.Qu'aurais-je du faire,l'Amie?Inventer?Qu'allais-je inventer-qui tienne l'homme droit, raidis dans mon adoration?Melanger de magies? Trouver au fond, tout au fond de moi, ce qui fait les femmes éternelles et ressemblantes?Ses misères n'étaient plus de mise, ces collisions de sentiments pour un ciel sans cause.Pourquoi seigneur? Pourquoi m'aije pas accouchée?"“
\end{abstract}

But Abdou no longer loves me...I knew it, I felt it. What would I have done, friend? To invent? What would I have invented that will keep a man right, radiant in my adoration? Mixed with magics. To discover deep, deep down in me, what makes women eternal and resemblance? These miseries were no longer obtainable, this collision of sentiments for a heaven without cause. Why Lord? Why was I not able to bear a child?

Beyala portrays the state of dissatisfaction and disillusionment characteristics of M'am, who wanted to get away from Mali by marrying Abdou so that she can live with him in France. She wanted to escape from the traditions and cultures of her African society. She longed for freedom like white women so that she can be liked by her counterparts and even the white women. She complains on Abdou not loving her again, she was not able to bear a child for him, talking about the plights of women despite the fact that he comes to warm himself in her bed.

\section{Neologism as a stylistic feature}

Neologism is otherwise called coinage. Neologism is a recurrent stylistic feature in Beyala's novels. Words are coined from Eton or French language. The words are deployed to show the identities of Beyala. Born in Eton, Beyala learned Eton and French languages in her primary schools. Examples of Eton and French words are found in TTT, MAA, and CSB.

\section{Excerpt 10:}

Tu vas mourir dans les cacas et la pissé (TTT : 60)

'monsieur a la plaire s'est baladie (TTT : 72)

Puisqu'il convient de commercer la chair

Seul quelques babingués' (TTT : 30)

English translation

You are going to die in the pou and the piss (TTT:160)

Monsieur a la plaire has gone astray (TTT:.72) 
Since it is necessary to trade the flesh

Only a few babingues (TTT:30)

The words "caca" and "pissé" are coined meaning "to defecate" and "to urinate". They simply mean to answer the call of nature. The literal translation would have been to it as pee, although this is informal and unacceptable. The choice of "caca" and "pissé" shows that Beyala associates with the downtrodden and the less privileged. She represents

Other Eton words are "Baladée" which means "to walk about" and "commercer la chair" meaning "to sell one's body". The idea conveyed in this line is that Beyala uses these words to show that women are cheap commodities and regarded as second class citizens. Their welfare is secondary because they are men's property. This is explicated in the TTT. The above words suggest that Ateda traded her body in order to cater for her family.

Babingués is another Eton word meaning "babing." It is the act of taking care of the young babies. In TTT, there are a number of Eton words such as "fauté' "classement des mots" and "Classement". For instance, "Classement” was a suffix meaning "placement." In MAA, Eton words are "putain” (p.10), “m'est avis” (p. 11), "le fric" (p.11), "mamzelle" (p. 11), "p'tit" (p.18), and "gonzesse" (p.24), while French words are "mon avis le franc", "les momes (p.36), and fiston (p. 29).

In CCM, Beyala uses Eton words in the title of her menu. such Eton words include the following: "Ngombo Au paprika" (p: 16), "Alieke aux crêvettes" (p: 56), "Gambas au epices" (p: 51) (spicy gambas) "Daurade aux piment rouges (p:65) (red chili sea bream), "Domba de macabo" (p: 103), "Saka saka aux feuilles de manioc ă la viande (p: 121) (saka saka with cassava leaves and meat), and "Crocodile ā la sauce (p: 129) (crocodile with sauce). Also, in CSB, "Feuilles de kwen" (p: 54) (kwen leaves), "Un hâa" (p:57) (a hast), "Froufrous d'une dentelle" (p59) (frilly of a lace), "Harreng fume" (p. 61) (smoked Harreng), "Safran et de morue chaud" (p: 74) (saffron and hot cod), "Mâ" (p: 101), "Gombo" (p: 106), and "Feuuille de myondo" (p :112) (myondo leaves) are Eton words.

Eton expressions are a characteristic stylistic feature of Beyalian novels. Here are examples in TTT, CSB, MAA, and CCM:

\section{Excerpt 11:}

Tu pues la mort TTT : 3 , (you stink like death.../you are about to die)

Tu as dix sept saisons. (TTT: 14).

You have seventeen season

meaning, you are 17 years old

From the excerpt above, it can be observed that "mort" is an Eton word meaning "one who smells" or "stinks". To stink means to stench, to be repulsive and to degenerate into a thing. Beyala uses the above word to show the enormity of social oppression and depression suffered by black women. The English translation uses the word seasons explicating "years". According to Yoruba adage, "Oba mewa igba mewa" ("ten kings ten seasons") shows that there are different kings and different leadership styles. Beyala uses the word "season" to show that Ateba is seventeen years old. This portrays that she is in a tender care and she is very inexperience. Therefore, engaging in prostitution at the age of seventeen is a social malady. This made her to experience serious headache because of the social subjugation, victimisation, and oppression, which she underwent. This is what made her to be lost in thought.

Meanwhile, some French words are coined. Such words include "Fiston" in MAA meaning "son", "franchouillard' in MAA meaning "one who is like a French man because he is a Senegalese", "derangement" in CSB derived from the verb derranger, "Le fric" in MAA derived from franc meaning the money; "putain" in MAA meaning "prostitute" (whore), M'amzelle in MAA explicaing "mademoiselle"; "recta" in MAA signifying direct (straight); and "filou" in MAA denoting (friend).

Furthermore, there are words borrowed from English. Such words include the following: walkman (MAA:11), (hold-up MAA: 25), chin-chin (MAA:71), bath (MAA: 42), cash (TTT:52), Formica (TTT:53), blacks (TTT:67), shit (TTT:80), business (TTT :132), and se love (TTT:172).

\section{Contraction of words}

A contraction refers to shortening of words. Words could be shortened for different purposes mostly in daily conversations. Contraction of words is commonly used in the street form of French language. In MAA, there are many instances of contractions of words. Here are examples: 


\title{
Excerpt 12:
}

\author{
M'es avis qu'il devrait faire, quéque, chose (A mon avis il devrant faire \\ qulque chose. \\ Meaning: in my opinion, he has to do something. \\ M'amzelle Esther... \\ Meaning: mademoiselle Esther \\ T'inquiète pas (p11) instead of "ne t 'inquiètes pas". \\ P'tit (p.18) meaning: "petit". \\ M'est avis (p.11) meaning: "ă mon avis" \\ P't-et (p.83). Meaning:" peut-être" \\ A vo’te souhait (p.80) meaning:" ā votre souhait".
}

From the excerpt above, it can be observed that many French words are contracted. For instance, "p'tit" is contracted as petit, "M'est avis" as "ă mon avis" and so on. The word "moiselle" is written as "demoi" is removed there by contracting the correct word. All these contractions are intentional and deliberate. Beyala uses contractions for stylistic purposes of signifying informality thereby associating with the downtrodden. Other examples of contraction of words include the following:

\section{Excerpt 13:}

M'est avis qu'il devait faire quelque chose.

In my opinion, he would have done something.

The "M" here is a pronoun, but being contrasted, it should be "Mon" avis. The sentence is a street French. Other manifestations of contractions are "T'inquiète pas, mec (You worry not guy in MAA:11). The "T" stands for the pronoun ' $\mathrm{Tu}$ ', but the sentence is not properly constructed. It should be "Ne t'inquietes pas mec. Because it is a street language, here the negation is omitted. The correct sentence should be "do not worry guy." Another example is Grand Dieu! Il faut l'voir pour l'croire! (Big God! You must see it to believe in MAA:12). It means that good God, seeing is believing. But the "i" is an article that replaces a pronoun, in two places, ' $i$ ' croire. The 'i' stands for "'le". Also, "T'es" vraiment sage; mon "p'tit" (MAA:14 You are really wise, my child). It means that you are really wise, my child. Here the "T" stands for "Tu" meaning "you" add the " $p$ " which is contrasted should be "petit", but unfortunately the 'e' was omitted. This is the way the immigrants of Belleville communicate with each other on a daily basis. The contraction of words are commonly deployed by Beyala. This is done by Beyala in order to associate with the less privilege.

In MAA, there are words that are contracted. The contracted words explicate French street language. This can be exemplified in the sentence such as "Il en est reste le cul sur le ciment" (He remains his bombom on the cement). The word 'cul' is a vulgar word in French. It is rather said 'Fesses'. Words like "'t'inquietes pas"' (MAA: 11 ) is used instead of 'ne t'inquiètes pas.' We say 'ne t'inquiètes pas' the ' ne'. It is the negation which is removed and it contrasted both the pronoun 'tu' plus the verb s'inquieter. In Mon p'tit (MAA:15), the word "Petit' is contrasted.

In some instances, we come across a word like "Quequi s'passe?'”Instead of "Que-ce-qui se passe?" What is happening? The word " que- ce qui" is contrasted as "se"'is. M'est avis que si ça continue (MAA:72). Here "m'est avis"' is contrasted as "A mon avis". Allez Bernard montre nous comment t'y fais (MAA:69). 'T'y", is supposed to be "'Tu', (T'inquiète pas M'am fait Fatima Peste, MAA:26). The word 'T'inquiète"' is contrasted as "Ne t'inquiètes pas".

Beyala uses the contraction of words to identify with the downtrodden and the less privilege. Beyala uses street French language, Eton words and loan words from English. These loan words help Beyala to thematise socio-political and religious issues.

\section{The use of pidgin French (Français Petit Nègre)}

Français Petit Nègre is a variety according to usage. It is regarded as the localised way through which Africans speak. It has no regards to the rules of grammar of the language particularly French. The pidgin French is the one spoken on the street among the illiterates. Instances of the pidgin French in Beyala's works include the following:

\section{Excerpt 14:}

TTT Les cacas et la pisse (p. 60) (cacas and piss)

Fous le camp! Salope (p. 57) get out! slut

Putes (whore) (p61) chie (wisdom) (p 62)

Louper (miss out on) (p 100) cafardeuse (dumps). (p 107) 
Les mecs (guys) (p 120).

It must be noted that all these words are pidgin French. Beyala uses these words to associate with the less privileged in the society. Words like "cacas" and "pissé" are deployed to show that Beyala is aware of the plights of the downtrodden. It must be said that the "les mecs" (guys) is used instead of men and women.

French pidgins are used in an unusual manner. Some words which are nouns are used as verbs. For instance, verbs such as 'Casser', 'têter,' 'attraper,' 'se reveiller', 'planter,' 'defiler,' 'seduire,' are used in the four texts with different meanings. The verb 'casser' (to break) is used in $C C M$, on page 26 'ah! ces Nègres alors...dit elle en cassant sa bouche a gauche." (Ah these Negers... she said by twisting her mouth, this connotation give the verb "caser' a scope of a meaning because in French one does not say 'you break the"). In CSB, the verb, "sedure" Il aurait fallu qu'elle sorte dans la rue séduire la pluie et le vent... CSB : 33. It means that she goes to the street to seduce the rain and the wind. This expression is metaphoric. Also, in TTT page 20, the verb "planter" Hassan s'est planté devant moi" in French one cannot say someone planted himself in one's front, we rather say "Il s'est placer devant moi.! He stood before me. All these are evidences of pidgin French in the works of Calixthe Beyala.

Direct Transfer of African Expression

Beyala uses African expressions into French language such expressions as follows:

\section{Excerpt 15:}

Te fais pas de mauvais sang, il m'a dit'

Don't do bad blood, he said to me (MAA:9)

meaning do not be wicked, bad blood connotes wickedness.

In TTT, 'un enfant doit garder les yeaux baissés' on page 16 (a child must keep his face down) means that a child must always be respectful. Expression such as l'enfant - parent de ses parents" TTT: 30 (a child-parent of her parents), the connotation is that the principle of life has been shifted to the child who now became the parent of her parents. In TTT, Tanga was speaking to her sister she said "Mais ton corps sent encore le lait" (TTT:98). It means that your body still smells milk and that she is still young.

In CCM and CSB, we have expressions such as "Mado avait plus de soixante saisons. Mado had more than 60 seasons. This means she is more than 60 years old. In CSB, "ceux qui troussent les culottes et oublient la carotte" (CSB:10) means those who make holes in short knickers and forget the calottes.

From the above expression, it is evident that the direct transposition of words is a basic characteristic of the Beyala's narratives. It is important to note that all other pidgins in Africa and the Carribeans are rooted in African linguistic repertoire. This evolves out of the friction between French and the African languages. That is the reason why some scholars classify it as part of African neologism or transliteration. But pidgin language generally is a broader encompassing linguistic creation where we find some types of Africanism in form of coinage and transliteration as well as some kinds of transposition.

\section{Conclusion}

This study has stylistically investigated selected works of Calixthe Beyala. It is observed that Beyala copiously used Eton, French, and English words and expressions in her narratives. Eton language explicates Beyala's African culture and traditions, while pidgin French signifies the fact that Beyala associates with the downtrodden. This is deployed through the use of street French language. The use of Eton words, which have no equivalence in both French and English, makes her narratives to be rich in the African tradition. Beyala's novels are characterized with stylo-linguistic features such as culture words, word clusters, neologism, contraction of words, pidgin French and direct transfer of African expression. Culture words show negritude experience of the African migrants, while words cluster reveal the depression suffered by Africans even in prisons. Neologism expresses creativity as well as foreground Beyala's identity. The use of contrasted French words by Beyala is deliberate and is deployed to express informality and conviviality of the writer to the socio-political issues. The contrasted words bridge the gap between the privilege and the less privilege. Pidginisation of French serves as an effective tool of communication and as a pragmatic instrument of developing French pidgin in Africa. Beyala uses pidgin French to enrich her African culture and tradition (Ashcroft, 1995: 286). Thus, Beyala uses both European and African languages in her works to thematise socio-political issues.

\section{References}

Primary sources

Beyala, C. (1987). C'est le soleil qui má brûlée. Oxford: Heinemann Educational Publishers 
-(1988). Tu táppelleas Tanga. Oxford: Heinemann Educational Publishers

(1998). Maman a un amant. Oxford: Heinemann Educational Publishers

(2000). Comment cuisiner son mari. Oxford: Heinemann Educational Publishers

Secondary sources

Adetuyi, C. (2017). Thematic preoccupation of Nigerian literature: a critical approach. Sciedu. Press. Pp 2126

Ayeleru, L.B. (2000). Stylistics: a survey of its role in literature in Ibadan. Journal of

European Studies, Vol. 1, 68.

------(2000). Literary idiolect in La vie,et demie et Létat honteux. A PhD thesis submitted to the Department of European Studies, University of Ibadan, Nigeria

----------(2002). La langue de la Literature Africaine Francophone: entre une identité et un hybride linguistigue. Journal of European Studies Vol 3.

Crystal, D. (1992). An encyclopedia dictionary of language. Oxford: basil Blackwell.

--------- English as a global language (second edition). Cambridge: Cambridge University Press.

Crystal, D. and Davy, D. (1969). Investigation English style. London: Longman

Halimi, M. S. (2015). From liberal-human orientations to existentialist human conduct: the transcendence of the woman's self. Humanities and Social Science. Volume 04 (01) pp209-217

Isidore, C. N. (2010). A linguistic stylistic analysis of Chukwuemeka Ike's novels. A Ph.D. Thesis submitted to the Department of English, University of Jos, Nigeria.

Leech. G. N. and Short. (1981). Style and fiction: a linguistic introduction in English fictional Prose. London and New York: Longman.

Leech, G. and Thomas, J. (1990). Language, meaning, and context. Pragmatics Encyclopedia of Language. London and New York: Routledge.

Magne, A. V. (2016). Freedom of female sexuality in Calixthe Beyala's C'est le soleil qui m'a brûlée: a critical analysis in translation. A dissertation submitted to the department of European Studies, University of the Witwatersrand

Mutunda, S. (2009). Through a female lens: aspects of masculinity in francophone African women's writing. A dissertation submitted to the Faculty of the Department of the French and Italian, University of Arizona.

Olayinka, E.B. (2014). Narrating juvenile mental disorders in Calixthe Beyala's selected novels. Nawa Journal of Language and Communication, Volume 8: Number 2. Pp 147-171

--------- (2018) Bodies that matter: Calixthe Beyala's female bodies and strategies of hegemonic subversion. Ufahamu: A journal of African Studies, 41(1). Pp 1-20.

Osundare, N. (2000). Style and literacy communication in African prose, fiction in English. Ibadan:Hope Publications.

Ogusiji, O.A. (2001). Decoding Soyinka's fiction: a linguistic stylistic study. A PhD thesis submitted to the Department of English University of Ibadan, Ibadan, Nigeria.

Spencer, J. (1964). Linguistics and style. London: Oxford University Press.

Turner, G. W. (1973). Stylistics. Great Britain: Harmondworth Penguin Press.

Thorne, J.P. (1970). Generative grammar and stylistic analysis: new horizons in linguistics. Great Britain: Hammondsworth Penguin. 